\title{
Analysis and modeling of moisture sorption behavior for antimicrobial composite protein films
}

\author{
QiaoLei ${ }^{\mathrm{a}, \mathrm{b}}$, Jiazhen Pan ${ }^{\mathrm{a}, *}$, JianqiangBao $^{\mathrm{b}}$, Zhiying Huang ${ }^{\mathrm{b}}$ and YutingZhang ${ }^{\mathrm{b}}$ \\ ${ }^{a}$ School of Mechanical and Power Engineering, East China University of Science and Technology, \\ Meilong Rd130, 200237, Shanghai, China \\ ${ }^{b}$ College of Food Science and Technology, Shanghai Ocean University, No. 999, Huchenghuan Rd, \\ Nanhui New City, 201306, Shanghai, China
}

\begin{abstract}
The WPI-NaCas-GLY antimicrobial film takes full advantage of the controlled release of active or antimicrobial agents as well as demonstrates a great potential for functioning as an alternative biodegradable polymer in practical applications. The moisture sorption kinetics of the film as an important carrier of active agents was investigated at various relative humidities (RH). The results indicated that the moisture sorption characterization and procedure of this film can be described well by the empirical Peleg model with higher confidence and concordance. The model could predict the film's moisture content at any time $\left(\mathrm{M}_{\mathrm{t}}\right)$, the time to reach any given level of $\mathrm{R}\left(\mathrm{t}_{\mathrm{R}}\right)$, the equilibrium moisture at any $\mathrm{RH}$ condition $\left(\mathrm{M}_{\mathrm{e}}\right)$, and isotherm trend based upon experimental data and modeled constants $\mathrm{k}_{1}, \mathrm{k}_{2}, \mathrm{a}, \mathrm{b}$, c, and d without giving consideration to their physical meaning. The water vapor transmission rate of the WPI-NaCas-GLY antimicrobial film increased exponentially with increasing RH due to its hydrophilicity, which was primarily caused by the presence of glycerol in a higher content. The results also suggested that $a_{w}$ predominately affects the film's $M_{e}$ values compared with the temperature factor by fixed nonlinear multiple regression analyses.
\end{abstract}

Keywords: WPI-NaCas-GLY antimicrobial film, Peleg model, moisture adsorption isotherm, water activity

\section{Introduction}

A Whey Protein Isolate (WPI)-sodium caseinate (NaCas)-glycerol (GLY) composite film was shown to be both smooth and transparent as well as displayed acceptable mechanical properties and made an excellent barrier against gas properties. In fact, it functioned better than the polyethylene packaging material used in previous works [1]. Increasing the WPI concentration resulted in decreased water solubility and gas barriers. NaCas, on the other hand, was efficient for improving both transparency and water solubility, although it decreased the barrier properties to some extent. Finally, an addition of glycerol stimulated an increase of elongation, water solubility, and flexibility, whereas the film tensile strength exhibited a reverse trend [1-3]. Thus, this film exhibited great potential for

\footnotetext{
*Corresponding author: Jiazhen Pan, School of Mechanical and Power Engineering, East China University of Science and Technology, Meilong Rd130, 200237, Shanghai, China. Tel.: 86-21-64252469; E-mail: jzpan@ecust.edu.cn.
}

0959-2989/14/\$27.50 @ 2014 - IOS Press and the authors. 
being an alternative biodegradable polymer in practical applications due to its unique packaging features.

Additionally, WPI-NaCas-GLY composite films can be used as active or antimicrobial packaging materials for foods by carrying antimicrobial agents, as they can both suppress microbial growth as well as limit the decomposition rate, which consequently provides significant safety and economic gains [4-6]. Microorganisms typically grow on foods' outer surfaces, and hence, the spoilage is located on the surface, as well. These films, however, deliver the preservative to the foods' surfaces, and limit preservative diffusion from the surface to the bulk of the food [7]. Being efficient carriers, they take advantage of the controlled release of various active or antimicrobial agents by modifying their water content, water activity, activation energy, and inner structure as hydrophilic polymers, beyond the range of Fick's and Henry's laws application.

The modeling and prediction of the transport performance of the hydrophilic films was highly complex for several reasons. First, the water sorption isotherms were highly non-linear, and the diffusivities in hydrophilic films strongly depended on the films' water content. In addition, mass transfer resistances in adjacent gas layers added an increasing level of complication. Finally, elements strongly affected the mass transfer resistances in the film itself. Moreover, empirical permeability measurements would be of limited utility if upstream and downstream humidities, temperatures, and mass transfer resistances were not specified [8].

The sorption characteristics of the WPI-NaCas-GLY composite film were crucial for the modification, modeling, and optimization of its forming, storage, and transport [9]. Moisture sorption isotherms provided sufficient information on materials' moisture-binding capacities at a determined relative humidity $(\mathrm{RH})$ and were a useful means of analyzing the moisture plasticizing effect and any effect on mechanical properties [9-11]. 23 isotherm models and their use for fitting both sorption isotherms of foods and food products have been reviewed by Chirife and Iglesias [9].

Moreover, empirical isotherm models from literature concerning the modeling of the experimental data of film samples' adsorption isotherms primarily includes the Guggenheim-Anderson-de Boer (GAB) model, Lewicki model, Oswin model, and Peleg model [9,12-14].

Each model has its own distinct set of advantages. For example, the GAB model is a semitheoretical multilayer sorption model with a physical meaning for each constant [15]. In general, it is regarded as the most accepted model for foods or edible films. The Lewicki model was developed to be applicable to a high range of $\mathrm{a}_{\mathrm{w}}$. It fit well with the moisture sorption data at higher humidity as well as predicted that the water content tended to infinity as $\mathrm{a}_{\mathrm{w}}$ reached 1.0. Thus, the Lewicki model is considered the preferable, more applicable model for predicting films' moisture adsorptions at different RHs [9]. The Oswin model gave excellent descriptions of the moisture isotherms throughout the entire range of $\mathrm{a}_{\mathrm{w}}$. Finally, the Peleg model could predict both sigmoid and non-sigmoid isotherms, which fit as well as or even better than the GAB model, though its constants had no physical meaning [9].

With the exploitation of increasing numbers of novel bio-functional and bio-medical materials or films, it is necessary to realize and analyze a film's characteristics in their entirety. Not only must the general mechanical and barrier properties be thoroughly examined, but the particular transmission and water sorption performances must also be characterized as well particularly as they play an important role in modifying the release of active or antimicrobial agents from the film to the food. The aim of this work is to analyze and model the moisture sorption capacity of the newly-exploited WPI-NaCasGLY antimicrobial film at different temperatures as well as different RH conditions by the Peleg model based on experimental data, regarding both this film's multivariate compositions as well as this 
model's goodness of fit, in order to predict the isotherm trend in addition to furthering the comprehension of the principles of transmission and adsorption for hydrophilic films.

\section{Materials and methods}

\subsection{Materials}

Whey protein isolate (WPI, protein $>92 \%$, fat $<1.8 \%$, lactose $<1.0 \%$ ) was obtained from the Hilmar Company (California, USA). Sodium caseinate (NaCas, with $92.9 \%$ protein) was supplied by the NZMP Company (New Zealand). Glycerol (GLY, analytical grade, SCRC, China) was used as a plasticizer to improve the films' flexibility properties [1]. Comverse dishes were purchased from the Jiangsu Taizhou Miwa Trading Co., Ltd, China. Lithium chloride ( $\mathrm{LiCl})$, magnesium chloride $\left(\mathrm{MgCl}_{2}\right)$, magnesium nitrate $\left(\mathrm{Mg}\left(\mathrm{NO}_{3}\right)_{2}\right)$, sodium chloride $(\mathrm{NaCl})$, potassium chloride $(\mathrm{Kcl})$, potassium nitrate $\left(\mathrm{KNO}_{3}\right)$ [9], and so on were all obtained from the Sigma Chemical Co. Nisin was supplied by the Zhejiang Yinxiang Bio-engineering Co., Ltd, China.

\subsection{Preparation of the antimicrobial composite protein film}

A composite protein film solution was prepared by dissolving $5 \mathrm{~g}$ whey protein isolate and $2 \mathrm{~g}$ NaCas into distilled water at $100 \mathrm{ml}$, respectively, while stirring until emulsification occurred, and a viscous and transparent solution was observed. The two solutions were then mixed. GLY was added to $50 \%(\mathrm{w} / \mathrm{w})$ of the total polymers as film plasticizers. $50 \mathrm{mg}$ nisin (activity $>1000 \mathrm{IU} / \mathrm{mg}$ ) was then added to the above film-forming solution in order to obtain antimicrobial efficacy. All solutions were degassed by a vacuum pump for $15 \mathrm{~min}$. The resulting solutions were then cast in $\mathrm{d}=90 \mathrm{~mm}$ polyacrylic plates and dried at $55^{\circ} \mathrm{C}$ in a ventilated oven for $5 \mathrm{~h}$. The obtained dry, solid films were peeled off and stored in a chamber at $50 \% \mathrm{RH}$ and $25^{\circ} \mathrm{C}$ until they were evaluated.

\subsection{Water vapor permeability of the composite protein film at various $R H$}

The water vapor permeability (WVP) of the films was measured according to the ASTM E398 [16] standard by a water permeability tester (PERMATRAN-W Model 1/50G, MOCON, USA). Tank pressure was set to $30 \mathrm{psig} \pm 2 \mathrm{psig}$ (approximately $0.2 \mathrm{MPa}$ ). The certified film (area of $30 \mathrm{~cm}^{2}$ ) was used to calibrate the instrument before sample testing. The $100 \% \mathrm{RH}$ test cell and saturated pad were used. Test mode was set to continuous, and the dry side set-point was $10 \%$; the test temperature was $37.8^{\circ} \mathrm{C}$, and the target range was set to a recommended value of 2 . For the hydrophilic characteristic of film-forming materials, the permeation $\mathrm{RH}$ was set at $40 \%, 50 \%, 60 \%$, and $70 \%$, respectively. A Precise RH Test Cell was used to test samples.

\subsection{Moisture sorption kinetics and isotherm of the film}

A standard gravimetric methodology (i.e. weighing samples equilibrated in thermally stabilized Comverse dishes) was used for determining the adsorption kinetics of the protein films. Film specimens $(25 \times 25 \mathrm{~mm})$ were thoroughly dried in the air blow oven at $60^{\circ} \mathrm{C}$ for $48 \mathrm{~h}$. The dried samples were placed into the inner ring of the Comverse dishes with saturated salt solutions in the 
outer ring and were then covered by a glass plate for sealing. Next, they were put into a climate chamber at 5,25 , and $40^{\circ} \mathrm{C}$, respectively. The salt solutions of known $\mathrm{RH}$ or $\mathrm{a}_{\mathrm{w}}$ are shown in Table 1.

The film samples' weights in definite temperature and RH conditions as a function of time were measured until the equilibrium was reached. Moisture adsorption curves of the films were suggested as fitting to a mathematical model by Peleg [9], which was given by:

$$
\begin{aligned}
& \mathrm{M}_{\mathrm{t}}=\mathrm{M}_{0}+\left[\mathrm{t} /\left(\mathrm{k}_{1}+\mathrm{k}_{2} \mathrm{t}\right)\right] \\
& \mathrm{M}_{\mathrm{e}}=\mathrm{M}_{0}+1 / \mathrm{k}_{2} \\
& \mathrm{dM}_{\mathrm{t}} / \mathrm{dt}=\mathrm{k}_{1} /\left(\mathrm{k}_{1}+\mathrm{k}_{2} \mathrm{t}\right)^{2} \\
& \mathrm{t} /\left[\mathrm{M}_{\mathrm{t}}-\mathrm{M}_{0}\right]=\mathrm{k}_{1}+\mathrm{k}_{2} \mathrm{t} \\
& \mathrm{R}=\left[\mathrm{M}_{\mathrm{t}}-\mathrm{M}_{0}\right] /\left[\mathrm{M}_{\mathrm{e}}-\mathrm{M}_{0}\right] \\
& \mathrm{t}_{\mathrm{R}} / \mathrm{t}_{1 / 2}=\mathrm{R} /(1-\mathrm{R})
\end{aligned}
$$

where $\mathrm{M}_{t}$ is the moisture after time $t, \mathrm{M}_{0}$ is the initial moisture, $\mathrm{k}_{1}$ and $\mathrm{k}_{2}$ are constants, $\mathrm{M}_{\mathrm{e}}$ is the equilibrium moisture, $\mathrm{dM}_{\mathrm{t}} / \mathrm{dt}$ is the momentary sorption rate, $\mathrm{R}$ is a ratio, $\mathrm{t}_{1 / 2}$ is the time needed to reach $\left[\mathrm{M}_{\mathrm{e}}-\mathrm{M}_{0}\right] / 2$, and $t_{\mathrm{R}}$ is the time to reach any given level of $\mathrm{R}$ [9]. Eq. (4) is a linear relationship form transformed from Eq. (1).

\subsection{Moisture sorption isotherm modeling}

The Peleg isotherm model from the literature [17] was selected for modeling the experimental data of adsorption isotherms of composite protein samples:

\begin{tabular}{|c|c|c|c|c|c|}
\hline $5^{\circ} \mathrm{C}$ & & $25^{\circ} \mathrm{C}$ & & $40^{\circ} \mathrm{C}$ & \\
\hline Salt & $a_{w}$ & Salt & $a_{w}$ & Salt & $a_{w}$ \\
\hline $\mathrm{LiCl} \cdot \mathrm{H}_{2} \mathrm{O}$ & 0.150 & $\mathrm{KOH}$ & 0.080 & $\mathrm{LiCl} \cdot \mathrm{H}_{2} \mathrm{O}$ & 0.112 \\
\hline $\mathrm{CH}_{3} \mathrm{COOK}$ & 0.225 & $\mathrm{LiCl} \cdot \mathrm{H}_{2} \mathrm{O}$ & 0.113 & $\mathrm{CH}_{3} \mathrm{COOK}$ & 0.200 \\
\hline $\mathrm{MgCl}_{2} \cdot 6 \mathrm{H}_{2} \mathrm{O}$ & 0.335 & $\mathrm{CH}_{3} \mathrm{COOK}$ & 0.225 & $\mathrm{MgCl}_{2} \cdot 6 \mathrm{H}_{2} \mathrm{O}$ & 0.320 \\
\hline $\mathrm{K}_{2} \mathrm{CO}_{3}$ & 0.460 & $\mathrm{MgCl}_{2} \cdot 6 \mathrm{H}_{2} \mathrm{O}$ & 0.328 & $\mathrm{Mg}(\mathrm{NO} 3)_{2} \cdot 6 \mathrm{H}_{2} \mathrm{O}$ & 0.482 \\
\hline $\mathrm{Mg}(\mathrm{NO} 3)_{2} \cdot 6 \mathrm{H}_{2} \mathrm{O}$ & 0.574 & $\mathrm{~K}_{2} \mathrm{CO}_{3}$ & 0.423 & $\mathrm{NaBr}$ & 0.532 \\
\hline $\mathrm{NaCl}$ & 0.765 & $\mathrm{Mg}(\mathrm{NO} 3)_{2} \cdot 6 \mathrm{H}_{2} \mathrm{O}$ & 0.529 & $\mathrm{NaCl}$ & 0.747 \\
\hline$\left(\mathrm{NH}_{4}\right)_{2} \mathrm{SO}_{4}$ & 0.812 & $\mathrm{CuCl}_{2} \cdot 2 \mathrm{H}_{2} \mathrm{O}$ & 0.675 & $\left(\mathrm{NH}_{4}\right)_{2} \mathrm{SO}_{4}$ & 0.790 \\
\hline $\mathrm{KCl}$ & 0.873 & $\mathrm{NaCl}$ & 0.753 & $\mathrm{KCl}$ & 0.832 \\
\hline $\mathrm{KNO}_{3}$ & 0.962 & $\left(\mathrm{NH}_{4}\right)_{2} \mathrm{SO}_{4}$ & 0.800 & $\mathrm{KNO}_{3}$ & 0.880 \\
\hline \multirow[t]{3}{*}{$\mathrm{K}_{2} \mathrm{SO}_{4}$} & 0.971 & $\mathrm{KCl}$ & 0.843 & $\mathrm{~K}_{2} \mathrm{SO}_{4}$ & 0.960 \\
\hline & & $\mathrm{KNO}_{3}$ & 0.925 & & \\
\hline & & $\mathrm{K}_{2} \mathrm{SO}_{4}$ & 0.970 & & \\
\hline
\end{tabular}

$$
\mathrm{M}_{\mathrm{e}}=\mathrm{a} \cdot \mathrm{a}_{\mathrm{w}}{ }^{\mathrm{b}}+\mathrm{c} \cdot \mathrm{a}_{\mathrm{w}}{ }^{\mathrm{d}}
$$

where $\mathrm{a}, \mathrm{b}, \mathrm{c}$, and d are constants.

Table 1

Water activities of different saturated salt solutions at 5,25 , and $40^{\circ} \mathrm{C}[8,12]$ 
2.6. Modeling the effects of both water activity and temperature on the moisture adsorption characteristic for antimicrobial composite protein films

The relationship and modeling functions of the three parameters $\left(\mathrm{M}_{\mathrm{e}}, \mathrm{a}_{\mathrm{w}}\right.$, and $\left.\mathrm{T}\right)$ was supposed as the following objective function:

$$
\mathrm{M}_{\mathrm{e}}=\mathrm{a}_{0}+\mathrm{a}_{1} \cdot \mathrm{T}+\mathrm{a}_{2} \cdot \mathrm{a}_{\mathrm{w}}+\mathrm{a}_{3} \cdot \mathrm{T}^{2}+\mathrm{a}_{4} \cdot \mathrm{T} \cdot \mathrm{a}_{\mathrm{w}}+\mathrm{a}_{5} \cdot \mathrm{a}_{\mathrm{w}}{ }^{2}
$$

where $\mathrm{a}_{0} \sim \mathrm{a}_{5}$ are regression coefficients.

\subsection{Statistical analysis}

Each experiment was performed in triplicate. Data points were represented by the mean [9], and the resulting data sets were then subjected to a fixed nonlinear regression statistical analysis using the program STATISTIC 6.0.

\section{Results and discussion}

\subsection{Effects of RH on the water vapor permeability (WVP) of antimicrobial composite protein films}

As the outside RH increased, there was a corresponding increase in the antimicrobial composite protein film's WVP (Figure 1), and the relationship between the two parameters can be described as an exponential equation, $\mathrm{WVP}=0.014 \mathrm{e}^{0.065 \mathrm{RH}}$, by fitting the experimental data. Because this is a factor of the film's hydrophilicity (whose barrier properties depend mainly on their water content and hence their $\mathrm{a}_{\mathrm{w}}$ ), Fick's and Henry's laws no longer applied. Under the action of water, the polymer swelled. This altered its structure and thus, made the diffusion of vapors or gases easier.

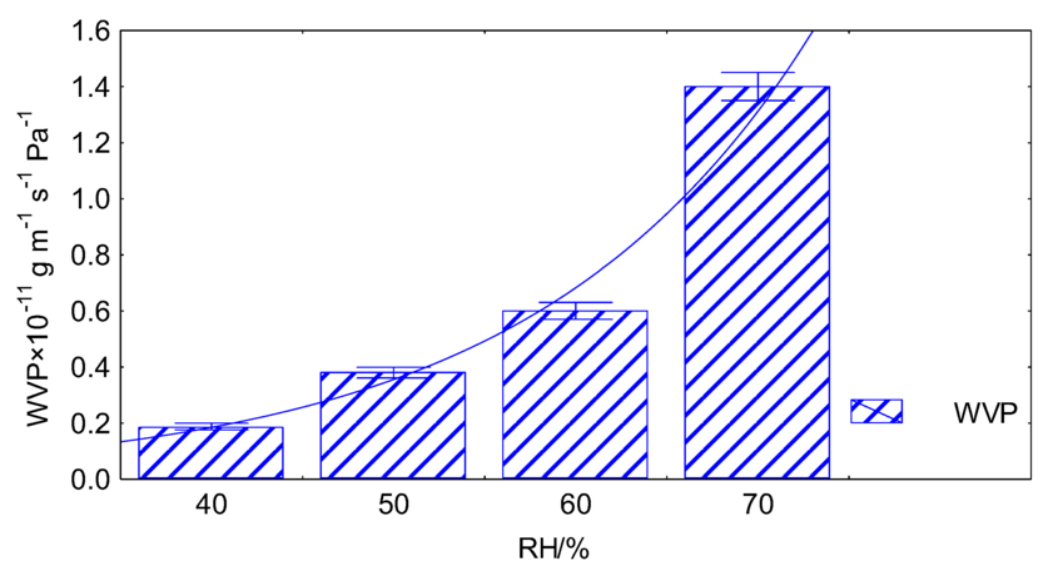

Fig. 1. WVP for antimicrobial composite protein film at various RHs. 


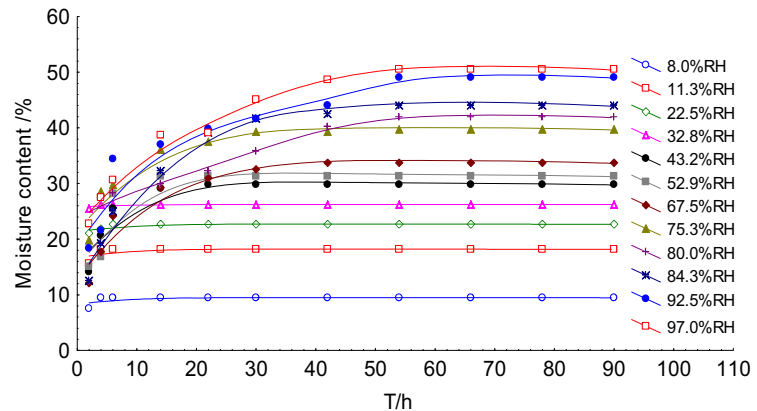

Fig. 2. Moisture sorption curves of antimicrobial films at $25^{\circ} \mathrm{C}$ and various $\mathrm{RHs}$ as a function of time.

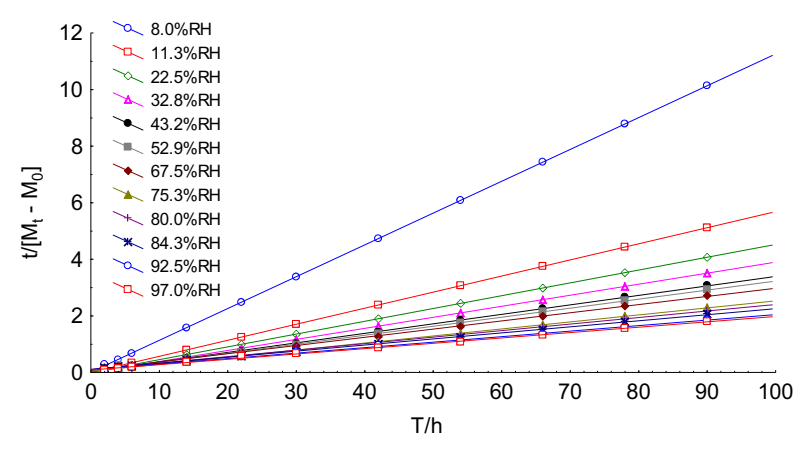

Fig. 3. Linearization of moisture sorption curves of the films at $25^{\circ} \mathrm{C}$ and various RHs as a function of time.

\subsection{Moisture adsorption kinetics}

The moisture sorption kinetic curves of the WPI-NaCas-GLY antimicrobial films at $25^{\circ} \mathrm{C}$ are depicted in Figure 2. Moisture adsorption was more rapid in the initial stages due to higher partial pressure grads of saturated vapor, but declined as time went on. The film's moisture content reached a plateau once becoming equilibrated with the $\mathrm{RH}$ in each condition. Additionally, it was revealed that the higher the $\mathrm{RH}$, the more adsorption time that is required to reach equilibrium which is consistent with Panuwat Suppakul's reports [9].

The measured sorption kinetic curve data shown in Figure 2 was fitted to Eq. (4) [9]. The fit of Eq. (4) to the sorption data and each linearization of the moisture sorption curve of the WPI-NaCas-GLY antimicrobial film are shown in Figure 3.

The constants $\mathrm{k}_{1}$ and $\mathrm{k}_{2}$ were derived from a linear fit as intercept and slope, respectively, and are shown in Table 2. The multiple related coefficients were found to be rather high in all cases (Multiple $\mathrm{R}>0.99$ ), which indicates a good fit to the sorption experimental data. The linear regression results

Table 2

Sorption kinetic model constants and moisture sorption parameters for antimicrobial films at $25^{\circ} \mathrm{C}$ and various RHs

\begin{tabular}{lllllllll}
\hline \multirow{2}{*}{$\begin{array}{l}\text { Relative } \\
\text { Humidity(\%) }\end{array}$} & \multicolumn{7}{l}{ Antimicrobial composite protein film } \\
\cline { 2 - 9 } & $\mathrm{k}_{1}$ & $\mathrm{k}_{2}$ & $\begin{array}{l}\text { Multiple } \\
\mathrm{R}\end{array}$ & $\begin{array}{l}\text { Measured } \mathrm{M}_{\mathrm{e}} \\
(\%)\end{array}$ & $\begin{array}{l}\text { Calculated } \mathrm{M}_{\mathrm{e}} \\
(\%)\end{array}$ & $\begin{array}{l}\mathrm{T}_{1 / 2} \\
(\mathrm{~h})\end{array}$ & $\begin{array}{l}\mathrm{T}_{\mathrm{R}} \\
(\mathrm{h}), \mathrm{R}=0.80\end{array}$ & $\begin{array}{l}\mathrm{T}_{\mathrm{R}} \\
(\mathrm{h}), \mathrm{R}=0.95\end{array}$ \\
\hline 8.0 & 0.014 & 0.112 & 0.99999 & $10.02 \pm 0.079$ & 9.53 & 0.1061 & 0.4246 & 2.0166 \\
11.3 & 0.004 & 0.057 & 0.99999 & $19.10 \pm 0.063$ & 18.14 & 0.0675 & 0.2699 & 1.2821 \\
22.5 & 0.003 & 0.045 & 0.99999 & $23.11 \pm 0.056$ & 22.82 & 0.0608 & 0.2432 & 1.1553 \\
32.8 & $5.101 \mathrm{e}-4$ & 0.039 & 0.99999 & $27.05 \pm 0.008$ & 26.24 & 0.0126 & 0.0505 & 0.2401 \\
43.2 & 0.041 & 0.034 & 0.99980 & $30.00 \pm 0.012$ & 30.01 & 1.1104 & 4.4418 & 21.0985 \\
52.9 & 0.046 & 0.032 & 0.99949 & $32.07 \pm 0.002$ & 31.85 & 1.3440 & 5.3762 & 25.5368 \\
67.5 & 0.090 & 0.029 & 0.99973 & $34.16 \pm 0.009$ & 35.08 & 2.7181 & 10.8723 & 51.6432 \\
75.3 & 0.045 & 0.025 & 0.99984 & $40.00 \pm 0.056$ & 40.60 & 1.6450 & 6.5799 & 31.2545 \\
80.0 & 0.103 & 0.023 & 0.99786 & $42.00 \pm 0.006$ & 44.08 & 3.8503 & 15.4012 & 73.1555 \\
84.3 & 0.115 & 0.021 & 0.99955 & $44.23 \pm 0.048$ & 48.22 & 4.3572 & 17.4286 & 82.7860 \\
92.5 & 0.104 & 0.019 & 0.99862 & $45.00 \pm 0.017$ & 53.23 & 3.8100 & 15.2402 & 72.3908 \\
97.0 & 0.089 & 0.019 & 0.99888 & $51.07 \pm 0.021$ & 53.23 & 4.1108 & 16.4431 & 78.1048 \\
\hline
\end{tabular}


indicated that the films that were placed at a higher RH tended to have lower $\mathrm{k}_{2}$ values, and vice versa. The $\mathrm{k}_{1}$ values, on the other hand, exhibited no such tendencies. As for the characterization constants for sorption behavior, the lower $\mathrm{k}_{1}$ was, the higher the initial moisture adsorption rate. In addition, the lower $\mathrm{k}_{2}$ was, the higher the moisture adsorption capacity [18].

The predictive capability of the Peleg model for the composite films was also demonstrated in Table 2, where the constants $k_{1}$ and $k_{2}$ were used to calculate the $M_{t}$ at any time in the entire range of the experiments. All of the experiments were of a $90 \mathrm{~h}$ duration (Figure 2), which is beyond the equilibrium level. Based on the Peleg model, the predicted or calculated $M_{e}$ values were slightly higher than the measured ones at an RH higher than $67.5 \%$, and vice versa. As can be seen from Table 2 , the time required to reach $\mathrm{R}=0.95$ (Eq. (5)) was nearly 20 times higher than required to reach $\mathrm{R}=1 / 2$.

Based on Eq. (4), $\mathrm{T}_{1 / 2}$ was deduced as follows:

$$
\mathrm{T}_{1 / 2}=\mathrm{k}_{1}\left(\mathrm{M}_{\mathrm{e}}-3 \mathrm{M}_{0}\right) /\left[2-\mathrm{k}_{2}\left(\mathrm{M}_{\mathrm{e}}-3 \mathrm{M}_{0}\right)\right]
$$

\subsection{Moisture adsorption isotherm}

Unlike many other polar polymers (classified as type II sigmoidal isotherms [19]) that are obtained for some edible materials and exhibit an asymptotic trend as $\mathrm{a}_{\mathrm{w}}$ moves toward 1.0 [9], the moisture sorption isotherm curve of antimicrobial composite protein films exhibits a non-typical and dramatic soaring of the characteristic at higher RH values under three temperature conditions. This is perhaps due to their individual chemical structures, degree of crystallinity, length of chains, lateral chains, and so on (Figure 4). Additionally, the moisture content of the antimicrobial composite protein films increased considerably, from $10.15 \%$ to $51.21 \%$ at $25^{\circ} \mathrm{C}$, as the surrounding $\mathrm{RH}$ rose from 8.0 to $97.0 \%$. In addition, the equilibrium moisture content of the film increased rapidly above $\mathrm{a}_{\mathrm{w}}=0.6$ at $40^{\circ} \mathrm{C}$ with some fluctuation, whereas it rose more steadily at $5^{\circ} \mathrm{C}$ and $25^{\circ} \mathrm{C}$. The trend at $40^{\circ} \mathrm{C}$ was, to some extent, more in accordance with the results from other edible films.

The glycerol that was added into this film was a hydrophilic plasticizer that loosened the film's structure and raised its hydrophilicity by exposing the hydroxyl groups. This significantly modified the moisture sorption behavior of the protein matrix and was the primary influence responsible for the higher moisture absorption characteristics displayed.

Temperature's influence on the antimicrobial WPI-NaCas-GLY film was not coherent with the endothermic nature of the water sorption process, which implied decreased water sorption capacity as the temperature increased [12]. At higher $\mathrm{a}_{\mathrm{w}}$ values, the water sorption capacity at $5^{\circ} \mathrm{C}$ was lower than those at 25 and $40^{\circ} \mathrm{C}$. It was suggested that temperature-dependant structural changes, such as crystallization, could occur to a different extent, thus affecting the water sorption behavior. The obtained water sorption results illustrated that, above $a_{w} 0.6$, crystal formation occurs to a greater extent at $5^{\circ} \mathrm{C}$; this, in turn, limits the location of polar water molecules, thus weakening the water sorption capacity of the protein matrices as compared with the data obtained at 25 and $40^{\circ} \mathrm{C}$.

Temperature affected the binding characteristics of water molecules in the film matrix. The temperature fluctuation resulted in a shift of the sorption isotherms, as shown in Figure 4, which meant that a temperature increase at a constant water content caused an increase in the water activity of foods, with the exception of those at $5^{\circ} \mathrm{C}$.

Based upon the principle that the water molecules were tightly bound in a monomolecular layer within range I $\left(a_{w}<0.3\right)$, and within range II $\left(0.3<a_{w}<0.75\right)$ they were less tightly bound so that they 


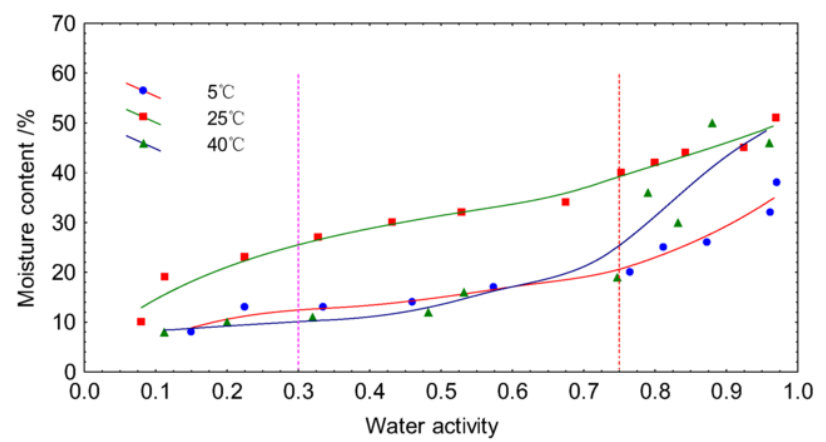

Fig. 4. Sorption isotherms of protein based films at 5,25 , and $40^{\circ} \mathrm{C}$.

could migrate and transport solutes, and finally, within range III $\left(a_{w}>0.75\right)$ they were present as free water, it became apparent that the stability characteristics of low moisture films are strongly influenced by a temperature change at a constant water content.

\subsection{The Peleg model of moisture adsorption isotherm for antimicrobial composite protein films}

Calculated model parameters, adjusted correlation coefficients, and p-level obtained by the fitting of the experimental data of the Peleg model for composite protein film are represented in Table 3. Results demonstrated that the relationship between $\mathrm{M}_{\mathrm{e}}$ and $\mathrm{a}_{\mathrm{w}}$ of the antimicrobial WPI-NaCas-GLY films could be well described by the Peleg model that had an advantage of modeling all data in the entire $\mathrm{a}_{\mathrm{w}}$ range (from 0.10 to 0.97 ).

In agreement with that previously mentioned, temperature-induced, notable changes in the Peleg constants due to a change in the sorption pattern caused by activation energy, crystallization, or water retention. In the case of the Peleg modeling, the $\mathrm{R}$ value was highest at $25^{\circ} \mathrm{C}$ but was slightly lower at $40^{\circ} \mathrm{C}$. With the experimental moisture content of the film versus the modeled moisture content of the film, the adjusted correlation coefficients for the Peleg model were 0.98509, 0.98717, and 0.94393, respectively, at $5^{\circ} \mathrm{C}, 25^{\circ} \mathrm{C}$, and $40^{\circ} \mathrm{C}$.

Table 3

Constants of the Peleg model $\left(\mathrm{M}_{\mathrm{e}}=\mathrm{a} \cdot \mathrm{a}_{\mathrm{w}}{ }^{\mathrm{b}}+\mathrm{c} \cdot \mathrm{a}_{\mathrm{w}}{ }^{\mathrm{d}}\right)$

\begin{tabular}{lllllll}
\hline Constants of & $5^{\circ} \mathrm{C}$ & & $25^{\circ} \mathrm{C}$ & & $40^{\circ} \mathrm{C}$ & \\
\cline { 2 - 7 } the Peleg model & Constants & p-level & Constants & p-level & Constants & p-level \\
\hline $\mathrm{a}$ & 20.68881 & 0.00332 & 9.432058 & 0.043737 & 9.09589 & 0.54216 \\
$\mathrm{~b}$ & 0.421236 & 0.061588 & 7.157139 & 0.280911 & 0.015597 & 0.986611 \\
$\mathrm{c}$ & 18.92243 & 0.00309 & 43.16367 & 0.00000 & 47.11316 & 0.01257 \\
$\mathrm{~d}$ & 7.346259 & 0.105543 & 0.449767 & 0.000120 & 3.327880 & 0.128678 \\
$\mathrm{R}$ & 0.98509 & & 0.98717 & & 0.94393 & \\
\hline
\end{tabular}

Table 4

Regression coefficients of the objective function on $\mathrm{M}_{\mathrm{e}}$

\begin{tabular}{lllllll}
\hline Regression coefficients & $\mathrm{a}_{0}$ & $\mathrm{a}_{1}$ & $\mathrm{a}_{2}$ & $\mathrm{a}_{3}$ & $\mathrm{a}_{4}$ & $\mathrm{a}_{5}$ \\
\hline Estimate & 3.693762 & 1.579415 & -10.5138 & -0.03964 & 0.551175 & 32.06268 \\
$\mathrm{p}$-level & 0.470572 & 0.000007 & 0.4938 & 0.00000 & 0.011576 & 0.01578 \\
$\mathrm{R}$ & 0.95013 & & & & & \\
\hline
\end{tabular}




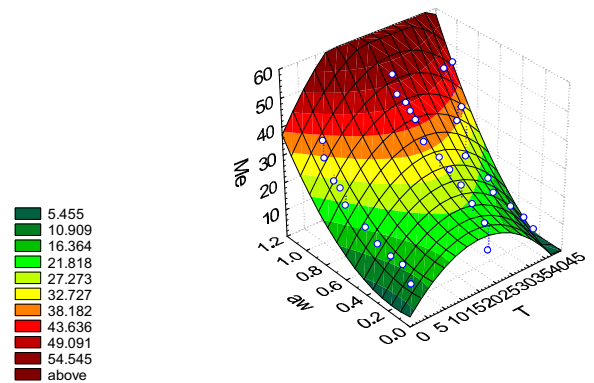

Fig. 5. 3D surface plot of $M_{e}$ values with changes to the temperature and water activity.

\subsection{Modeling the influence of both $a_{\mathrm{w}}$ and temperature on the moisture adsorption characteristic for antimicrobial composite protein films}

Figure 5 represents a 3D surface plot of $\mathrm{M}_{\mathrm{e}}$ values with changes to the two independent variables, which were water activity and temperature, respectively. The regression coefficients in Eq. (8) (that were obtained by fixed nonlinear multiple regression analyses on the experimental values shown in Figure 5) are listed in Table 4, and suggest that, along with being correlated with the temperature, $\mathrm{a}_{\mathrm{w}}$ predominately affects the $\mathrm{M}_{\mathrm{e}}$ values. The mathematical correlation between the three parameters can be accurately modeled by Eq. (10):

$$
\mathrm{M}_{\mathrm{e}}=3.694+1.579 \cdot \mathrm{T}-10.514 \cdot \mathrm{a}_{\mathrm{w}}-0.04 \cdot \mathrm{T}^{2}+0.551 \cdot \mathrm{T} \cdot \mathrm{a}_{\mathrm{w}}+32.063 \cdot \mathrm{a}_{\mathrm{w}}{ }^{2}
$$

\section{Conclusion}

WPI-NaCas-GLY antimicrobial films fully take advantage of the controlled release of active or antimicrobial agents as well as demonstrate great potential for functioning as alternative biodegradable polymer in practical applications. The water vapor permeability of the WPI-NaCas-GLY antimicrobial film exponentially increased with increasing RH due to its hydrophilicity, which was primarily caused by the presence of glycerol in a higher content. The moisture sorption characterization and procedure of this film was described by the empirical Peleg model with higher confidence and concordance. Based on experimental data and on the modeled constants $\mathrm{k}_{1}, \mathrm{k}_{2}, \mathrm{a}, \mathrm{b}$, c, and $\mathrm{d}$ without any consideration to their physical meaning, the model could predict the film's moisture content at any time $\left(\mathrm{M}_{\mathrm{t}}\right)$, the sorption time to reach any given level of $\mathrm{R}\left(\mathrm{t}_{\mathrm{R}}\right)$, the equilibrium moisture at any $\mathrm{RH}$ condition $\left(\mathrm{M}_{\mathrm{e}}\right)$, and the isotherm trend. Results also suggested that $\mathrm{a}_{\mathrm{w}}$ predominately affects the film's $\mathrm{M}_{\mathrm{e}}$ values compared with the temperature factor by fixed nonlinear multiple regression analyses.

Furthermore, the results implied that a moderate hydrophilicity assisted in making the WPI-NaCasGLY antimicrobial film an important carrier capable of transporting or releasing active antimicrobial agents from the film to the food's surface. Thus, this film has great potential for use as a functional or edible film for food packaging by moisture-resistant modification.

All phenomena occurring during the film's use and storage were not predictable from a theoretical model due to the complexity and heterogeneity of the medium. However, parallel studies on model systems and observations of real products should result in increasingly accurate information on the relationship between water interactions and film characterization. 


\section{Acknowledgment}

This work was financed by the Shanghai University Knowledge Service Platform and Shanghai Ocean University aquatic animal breeding center (ZF1206), and it was also supported by the IndustryAcademy-Research cooperation project from the Shanghai City Board of Education. The authors gratefully acknowledge their support.

\section{References}

[1] G.Y. Chen and Q. Lei, Research on preparation and properties of edible composite protein films, Applied Mechanics and Materials 87 (2011), 213-222.

[2] J. Oses, M. Fabregat-Vazquez, R. Pedroza-Islas, S.A. Tomas, A. Cruz-Orea and J.I. Mate, Development and characterization of composite edible films based on whey protein isolate and mesquite gum, Journal of Food Engineering 92 (2009), 56-62.

[3] X.L. Yu, G.H. Zhou and X.B. Li, The application of Sodium alginate based edible films in food processing industry, Food Research and Development 9 (2009), 181-184.

[4] M. Ozdemir and J.D. Floros, Optimization of edible whey protein films containing preservatives for water vapor permeability, water solubility and sensory characteristics, Journal of Food Engineering 86 (2008), 215-224.

[5] Q. Lei, Z.Y. Huang and J.Z. Pan, Research on antimicrobial activity and packaging performance of degradable protein films, Advanced Materials Research $915-916$ (2014), 947-953.

[6] Z.Y. Huang and Q. Lei, Research on antimicrobial activity of functional protein films, Advanced Materials Research 785-786 (2013), 660-665.

[7] M. Ozdemir and J.D. Floros, Analysis and modeling of potassium sorbate diffusion through edible whey protein films, Journal of Food Engineering 47 (2001), 149-155.

[8] Henry G. Schwartzberg, Modeling of gas and vapour transport through hydrophilic films, in: Food Packaging and Preservation: Theory and Practice, Elsevier Applied Science Publishers, New York, 1986, pp. 115-123.

[9] Panuwat Suppakul, Buppa Chalernsook and Bhatama Ratisuthawat, Empirical modeling of moisture sorption characteristics and mechanical and barrier properties of cassava flour film and their relation to plasticizingantiplasticizing effects, LWT-Food Science and Technology 50 (2013), 290-297.

[10] A.H. Al-Muhtaseb, W.A.M. McMinn and T.R.A. Magee, Moisture sorption isotherm characteristics of food products: A review, Transactions of Institution of Chemical Engineers 80 (2002), 118-128.

[11] L.N. Bell and T.P. Labuza, Moisture Sorption: Practical Aspects of Isotherm Measurement and Use, 2nd ed., American Association of Cereal Chemists, Inc., St. Paul, 2000.

[12] A. Jimenez, M.J. Fabra, P. Talens and A. Chiralt, Phase transitions in starch based films containing fatty acids, Effect on water sorption and mechanical behaviour, Food Hydrocolloids 30 (2013), 408-418.

[13] John N. Coupland, Niamh B. Shaw and Frank J. Monahan, Modeling the effect of glycerol on the moisture sorption behavior of whey protein edible films, Journal of Food Engineering 43 (2000), 25-30.

[14] Jun-Feng Su, Zhen Huang and Ying-Hui Zhao, Moisture sorption and water vapor permeability of soy protein isolate/poly (vinyl alcohol)/glycerol blend films, Industrial Crops and Products 31 (2010), 266-276.

[15] E.O. Timmerman, J. Chirife and H.A. Iglesias, Water sorption isotherms of foods and foodstuffs: BET or GAB parameters? Journal of Food Engineering 48 (2001), 19-31.

[16] ASTM E 398, Standard test method for water vapor transmission rate of sheet materials using dynamic relative humidity measurement, in: Annual Book of ASTM Standards, PA: American Society for Testing and Materials, Philadelphia, 2003.

[17] R.T. Toledo, Fundamentals of Food Processing Engineering, 2nd ed., Van Nostrand Reinhold, New York, 1991.

[18] M. Turhan, S. Sayar and S. Gunasekaran, Application of Peleg model to study water absorption in chickpea during soaking, Journal of Food Engineering 53 (2002), 153-159.

[19] M. Mathlouthi and B. Rogé, Water vapour sorption isotherms and the caking of food powders, Food Chemistry 82 (2003), 61-71. 